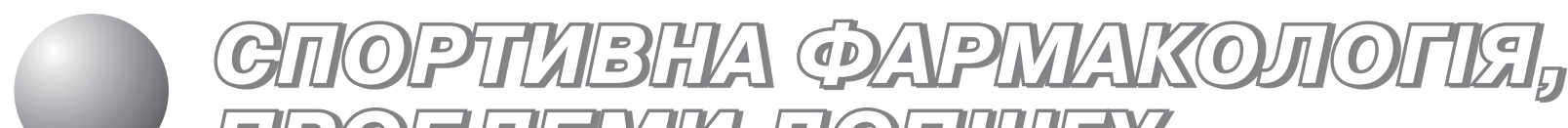

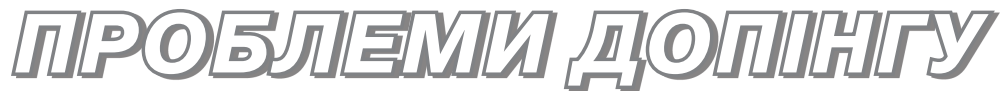

\section{Корекція стану регуляторних механізмів серця та працездатності спринтерів}

\section{3. І. Коритко}

Львівський державний університет фізичної культури, Львів, Україна

\begin{abstract}
Резюме. Проанализированы три препарата Омега-3 разного происхождения с разным жирнокислотным составом. Установлено, что все препараты приводили к одновекторным положительным изменениям, которые сопровождались ростом ВСР с усилением активности автономного контура и повышением работоспособности. Доказано, что для формирования функционального резерва спринтерам достаточно 300 мг Омега-3 животного или 600 мг растительного происхождения в сутки в течение месяца.
\end{abstract}

Ключевые слова: Омега-3, вариабельность сердечного ритма, работоспособность, спринтеры

Summary. Omega-3 preparations of different origin with different fatty-acid content have been analyzed. All preparations have resulted in single-vector positive changes accompanied by increase of VSR with enhanced activity of autonomous contour and work capacity improvement. It has been proved that $300 \mathrm{mg}$ of Omega-3 of animal or $600 \mathrm{mg}$ of vegetable origin per day during one month are sufficient for functional reserve formation in sprinters.

Key words: Omega-3, heart rate variability, work capacity, sprinters.

Постановка проблеми. У сучасному спорті важливе місце у вирішенні проблеми підвищення фрізичної працездатності належить фрармакологічній підтримці спортсменів, оскільки на сьогодні вже важко досягнути високих спортивних результатів лише за рахунок збільшення об'єму та інтенсивності тренувальних навантажень.

Серед величезної кількості медико-біологічних засобів, які сприяють пришвидшенню процесів відновлення, збільшенню фрункціональних резервів та підвищенню працездатності, особливе місце займають природні адаптогени, оскільки вони мають достатньо м'яку дію, можуть тривало застосуватись, і володіють позитивним біологічним ефектом, який наступає незалежно від спрямованості попередніх зрушень. Одним із таких природних засобів $€$ поліненасичені жирні кислоти (ПНЖК) Омега-3, що мають поліфакторний вплив на всі системи організму $[2,7,8,26]$ і дістали широке використання в клініці як допоміжний засіб при лікуванні багатьох патологій $[11,13,14,16,17,22]$.
Водночас у літературі практично відсутні дані про використання ПНЖК Омега-3 для підвищення фрункціональних резервів та працездатності спортсменів $[3,5,9,10]$. Разом із тим на ринку $€$ десятки препаратів тваринних та рослинних джерел Омега-3 із різним співвідношенням $\alpha$-лінолевої (АЛК), ейкозапентаєнової (ЕПК) та докозагексаєнової (ДГК) кислот та інших ПНЖК, а також із різними вітамінами та мікроелементами, що утруднює вибір препарату. Також важко зорієнтуватись і у дозуванні препаратів, оскільки американською асоціацією кардіологів рекомендовано вживати 300 мг ЕПК/ДГК на добу здоровим особам із профрілактичною метою і близько 1 г - хворим на ішемічну хворобу серця [23]. Інші джерела стверджують, що кількість Омега-3 для хворих може бути збільшена до 4 г на добу [1], а МОЗ Росії рекомендує для адекватного споживання 1 г АЛК/ЕПК/ДГК на добу [12].

Роботу виконано за темою Львівського державного університету фрізичної культури «Моніторинг процесу адаптації висококваліфікованих 
Рисунок 1 - Зміни спектральних параметрів варіабельності ритму серця під впливом прийому ПНЖК Омега-3 олії з насіння льону

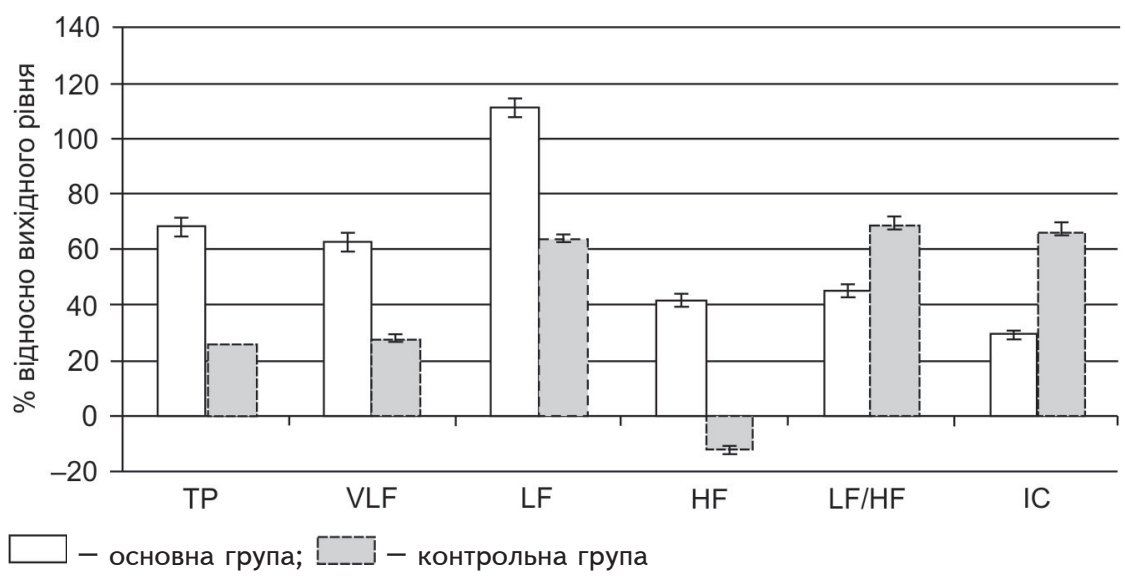

спортсменів з урахуванням індивідуальних особливостей» (номер держреєстрації 0111U001732).

Мета досліджень - з'ясування ефективності впливу різних джерел Омега-3 на стан регуляторних механізмів серця та працездатність спринтерів.

Методи та організація дослідження. У трьох серіях досліджень із використанням груп сліпого плацебо-контролю до і після місячного курсу прийому препаратів (I і II етапи досліджень) в основних групах (ОГ1, ОГ2 і ОГЗ) та контрольних групах (КГ1, КГ2 і КГЗ) бігунів на короткі дистанції чоловічої статі віком 18-20 років проаналізовано результати велоергометричного тесту Конконі [20], показники спеціальної працездатності, зміни спектральних і часових параметрів ВСР, отриманих за допомогою автоматизованої комп'ютерної програми CardioLab (Харків), та показники D-димерів - маркера коагуляції та фрібринолізу [21]. Згідно з середніми величинами, рекомендованими інструкціями препаратів, спринтери ОГ1 споживали на добу 600 мг ПНЖК Омега-3 рослинного походження (переважно АЛК) - препарат «ПНЖК Омега-3 олії з насіння льону» (RealCaps, Росія); ОГ2 - 300 мг Омега-3 концентрату морських ліпідів (180 мг ЕПГ і 120 мг ДГК) - препарат «Омега-3 ЕРА» (Neways, США); ОГ3 - 1000 мг Омега-3 (300 мг ДГК, 200 мг ЕПК і 500 мг інших жирних кислот із достатньо широким спектром вітамінів та мікроелементів) - препарат «Вітрум Кардіо Омега-3» (Unipharm, США). У всіх обстежуваних отримано інформовану згоду і узгоджено з Комісією 3 Біоетики. Дані статистично опрацьовані.

Результати дослідження та їх обговорення. Отримано практично однакові зміни регуляторних механізмів серця у спортсменів ОГ1-ОГЗ, які приймали різну дозу Омега-3 з різним жирнокислотним складом. На прикладі впливу АЛК (попередника ейкозаноїдів) ПНЖК олії з насіння льону видно (рис. 1), що після курсу прийому препарату зросла загальна варіабельність за показником TP (на 68,2 \%; p < 0,05) з пропорційним зростанням усіх складових спектра (VLF, LF i HF; $p<0,05)$. Водночас у спринтерів ОГ, порівняно з КГ, ПНЖК сприяли вирівнюванню балансу нервових і гуморальних впливів на серце (зменшення симпато-вагального індексу - LF/HF), зниженню індексу централізації (IC) і посиленню активності автономного контуру (зростання високочастотної складової спектра коливань - HF) (на $40 \% ; p<0,01)$.

У спринтерів КГ на другому етапі досліджень під впливом тренувальних навантажень підготовчого періоду на фроні прийому плацебо, навпаки, спостерігали підвищення впливу вазомоторного центру та інших ієрархічних рівнів регуляції на роботу автономного контуру і зміщення рівноваги в бік переважання симпатичної регуляції ритмом серця, на що вказувала виражена тенденція до зростання симпато-вагального індексу (на $85,1 \%, p>0,05)($ з $0,94 \pm 0,33$ - на І етапі досліджень до 1,74 \pm 0,89 - на II етапі досліджень) та індексу централізації (на $66,1 \%$, р 0,05) зі зростанням стрес-індексу (на $27,4 \%$, р $<0,05$ ) (див. рис. 1, табл. 1).

Після фрізичного навантаження «до відмови» у спринтерів КГ1-КГЗ на другому етапі досліджень на фоні прийому плацебо під впливом тренувальних навантажень підготовчого періоду відмічено ще більше підвищення рівня активності вазомоторного центру з переважанням центрального контуру регуляції над автономним, що продемонстровано зростанням у КГ1 стрес-індексу на $18,9 \%(p<0,05)$ і тенденцією до зростання індексу централізації (на $51,4 \%$, p > 0,05) (табл. 1).

Відмічено, що після граничного фрізичного навантаження зміни, які відбулись у спортсменів ОГ1-ОГЗ під впливом різних джерел ПНЖК 
ТАБЛИЦЯ 1 - Зміни індексів LF/HF, SI та IC варіабельності ритму серця у спринтерів за умов прийому ПНЖК Омега-3 олії з насіння льону

\begin{tabular}{|c|c|c|c|c|c|}
\hline \multirow{3}{*}{ Показник } & \multirow{3}{*}{ Умови } & \multicolumn{2}{|c|}{ ОГ (n = 15) } & \multicolumn{2}{|c|}{$\kappa \Gamma(n=15)$} \\
\hline & & \multicolumn{4}{|c|}{ Етап } \\
\hline & & 1 & II & 1 & II \\
\hline \multirow[t]{2}{*}{$L F / H F$} & До фрізичного навантаження & $0,71 \pm 0,27$ & $0,94 \pm 0,33$ & $1,03 \pm 0,41$ & $1,74 \pm 0,89$ \\
\hline & Після фізичного навантаження & $5,22 \pm 1,91$ & $3,36 \pm 1,1$ & $4,1 \pm 1,12$ & $3,86 \pm 0,96$ \\
\hline & & $p<0,05$ & $p<0,05$ & $p<0,05$ & $p>0,05$ \\
\hline \multirow[t]{2}{*}{ SI } & До фізичного навантаження & $81,0 \pm 9,93$ & $94,0 \pm 8,85$ & $105,8 \pm 9,12$ & $134,8 \pm 7,5^{\star * *}$ \\
\hline & Після фрізичного навантаження & $227,4 \pm 15,3$ & $151,3 \pm 23,2^{*}$ & $378,8 \pm 37,6^{*}$ & $449,0 \pm 13,1^{* *}$ \\
\hline & & $p<0,01$ & $p<0,05$ & $p<0,01$ & $p<0,01$ \\
\hline \multirow[t]{3}{*}{ IC } & До фізичного навантаження & $1,53 \pm 0,5$ & $1,86 \pm 0,65$ & $1,98 \pm 0,3$ & $3,09 \pm 0,69$ \\
\hline & Після фрізичного навантаження & $9,6 \pm 1,8$ & $5,87 \pm 1,35$ & $4,69 \pm 1,57$ & $7,1 \pm 1,4$ \\
\hline & & $p<0,01$ & $p<0,01$ & $p<0,01$ & $p>0,05$ \\
\hline
\end{tabular}

${ }^{*} p<0,05 .{ }^{* \star} p<0,01-$ вірогідність між етапами. ${ }^{* * *} p<0,05 .{ }^{* * *} p<0,01-$ вірогідність між ОГі КГ.

Омега-3, свідчать про однаковий вектор їхніх дій, який для здорових кваліфікованих бігунів віком 18-20 років особливо не залежав від збільшення дози ПНЖК (рис. 2). Водночас відмінності між спортсменами ОГ1-ОГЗ та КГ1-КГЗ (див. рис. 2, табл. 1) під час виконання граничної фрізичної роботи «до відмови» вказували на створення у цих бігунів значного фрункціонального резерву під впливом прийому всіх препаратів, на основі якого зростала загальна та спеціальна фрізична працездатність (рис. 3, 4).

Прийом усіх трьох препаратів приводив до зростання працездатності спортсменів, підвищував поріг аеробно-анаеробного переходу (ПАНО), підвищував величину частоти серцевих скорочень при ПАНО (ЧСС сягненні ПАНО (tПАНО) ( $<<0,05)$ (див. рис. 3).

Під впливом різних джерел ПНЖК Омега-3 зростали загальна потужність навантаження тесту Конконі (на 6-8 \%; р $<0,01$ ) і тривалість роботи «до відмови» (на $5-7 \%$; $<<0,01$ ) у спортсменів
ОГ1-ОГЗ. У спортсменів, які приймали плацебо, цей показник протягом місяця зріс лише на незначну величину (близько $1 \% ; p>0,05)$.

В результаті прийому Омега-3 у групах ОГ1ОГЗ зросли також показники спеціальної фрізичної підготовленості, що показано на прикладі впливу ПНЖК з рослинних джерел (див. рис. 4).

Слід зауважити, що ПНЖК Омега-3 є потужним антиоксидантом, який має здатність впливати на працездатність людини [2, 8], в основному в аеробно-анаеробній зоні продукції енергії, на що вказує підвищення під дією препаратів рівня ЧСС нального і метаболічного резерву організму під впливом ПНЖК Омега-3 супроводжується високою інтенсивністю окисно-відновних процесів [4], які не мають прямого відношення до швидкісних якостей спринтерів, енергозабезпечення роботи яких відбувається за рахунок анаеробних механізмів. Слід відмітити, що механізм дії Омега-3 ПНЖК досить складний, що забезпечує
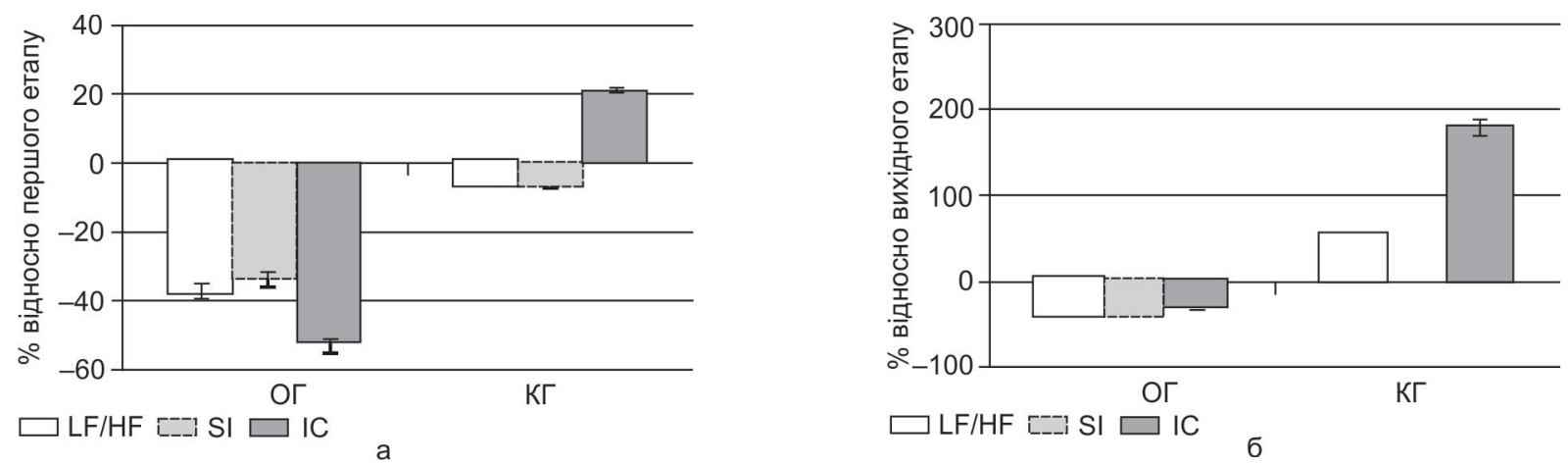

Рисунок 2 - Зміни індексів (LF/HF, SI та IC) у спринтерів основних груп (ОГ) і контрольних (КГ) після фрізичного навантаження за умов прийому ПНЖК Омега-3:

а -ПНЖК Омега-3 олії з насіння льону і б - Вітрум Кардіо Омега-3 

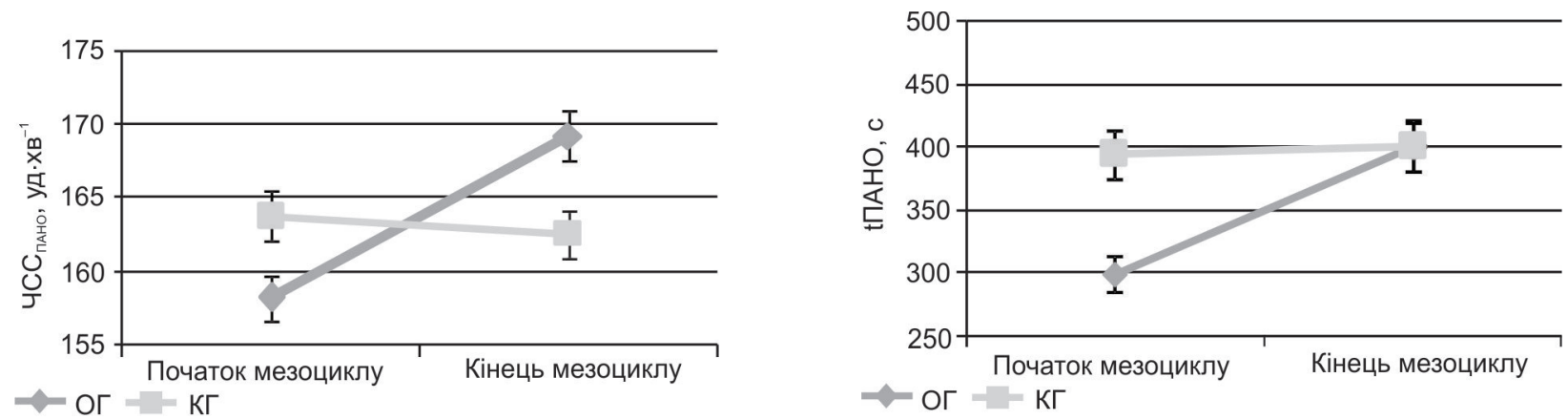

Рисунок 3 - Вплив Омега-3 олії з насіння льону на показники працездатності спринтерів основних груп (ОГ) та контрольних (КГ) при виконанні тесту Конконі

їм достатньо широкий спектр фрармакологічного впливу $[2,8,12,26]$. Крім попередження розвитку окисного стресу, що властивий спортсменам, які регулярно піддаються значним фрізичним навантаженням [4], ПНЖК Омега-3 здатні підвищувати стресостійкість і адаптаційний потенціал $[5,10]$, оскільки вони є важливими структурно-функціональними елементами клітинних мембран, підвищують їх проникність, модулюють функції мембранних білків [19]. Механізм дії Омега-3 ПНЖК як важливого елемента клітинних мембран переважно пов'язаний з їх впливом на метаболізм арахідонової кислоти (Омега-6). Омега-3 ПНЖК $\epsilon$ конкурентними антагоністами арахідонової кислоти і зменшують вміст арахідонової кислоти та її метаболітів в організмі - тромбоксану $A_{2}$, лейкотрієнів, що пояснює наявність у Омега-3 ПНЖК антиагрегантних, протизапальних та гіпотензивних властивостей [2, 19, 24, 25]. Омега-3 ПНЖК, конкуруючи з арахідоновою кислотою, заміщають її в мембранах і тим самим підвищують їх проникність, модулюють фрункції мембранних білків, що покращує ендотеліальну функцію, має протизапальні властивості $[22,24]$. Крім того, ПНЖК Омега-3 мають антикоагулянтні властивості, які полягають у гальмуванні процесу синтезу білків типу тромбоксану $A_{2}$, під впливом яких відбувається утворення тромбів у кровоносних судинах, зменшують продукцію індукторів запалення й агрегації тромбоцитів, метаболітів, які мають вазоконстрикторну дію [27], що сприяє покращенню реологічних властивостей крові, які знижуються у спортсменів за умов значних ФН [15]. Такий вектор фрункціонально-метаболічних змін під час вживання ПНЖК Омега-3 дозволяє забезпечити кращу толерантність до фрізичних навантажень і сприяє підвищенню фоункціональних можливостей та працездатності спортсменів.

Широкий спектр фрармакологічного впливу i нові ефекти, що відкривають дослідники від вживання ПНЖК Омега-3, можна також пояснити 3 точки зору фрункціонування тромбін-плазмінової системи (ТПС) організму, яка функціонує у всіх його біологічних середовищах як єдиний коагуляційно-регенераційний механізм (КРМ), що забезпечує структурно-фрункціональний рівень за умов фізіологічних та патологічних впливів [6]. Згідно КРМ, залежно від ступеня переважання процесів коагуляції (активації підсистеми тромбіну) чи регенерації (активації підсистеми плазміну) в основних

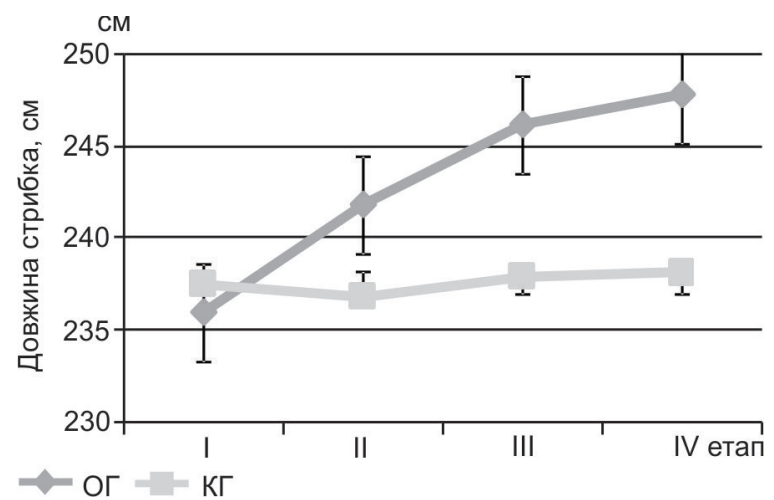

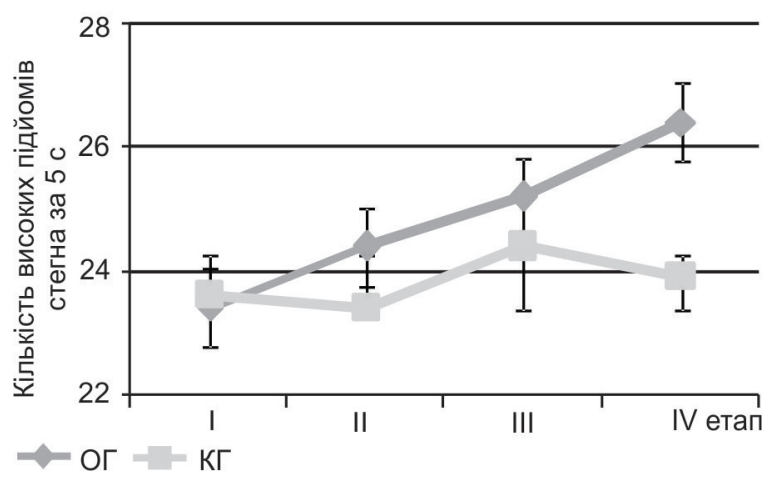

Рисунок 4 - Показники фрізичної підготовленості у основних групах (ОГ) та контрольних (КГ) на різних етапах прийому Омега-3 олії з насіння льону 
біологічних середовищах організму (крові, проміжній сполучній тканині та цитоплазмі клітин) відбуваються протилежні зміни структури і функції на різних рівнях організації [6].

Оскільки ПНЖК Омега-3 володіють антикоагулянтними і фрібринолітичними властивостями $[2,15]$, то, очевидно, оптимізують фрункціональний стан ТПС, вирівнюючи баланс між активацією підсистем тромбіну та плазміну, на що вказує зниження концентрації D-димерів після ФН. Впливом ПНЖК Омега-3 на протилежні важелі ТПС (підсистем тромбіну і підсистеми плазміну) можна, очевидно, пояснити забезпечення структурно-функціонально-метаболічнгого гомеостазу у спортсменів за умов граничних $Ф \mathrm{H}$, результатом якого $\epsilon$ зміни у фрізичних та фрункціональних можливостях.

\section{Література}

1. АроноВ Д. М. Сердечно-сосудистая система и Омега-3 полиненасыщенные жирные кислоты / Д. М. Аронов // Кардиология. - Режим доступу: http://www.rusmg.ru/ php/contents.php?group $=144$

2. Гаßрисюк В. К. Применение Омега-3 полиненасыщенных жирных кислот в медицине / В. К. Гаврисюк // Укр. пульмонол. журн. - 2001. - № 3. - С. 5-10.

3. Коритко 3. Вплив рослинних адаптогенів на працездатність та показники швидкісно-силової підготовки легкоатлетів-спринтерів / З. Коритко, С. Онищук, Н. Семенова // Молода спорт. наука України. - 2010. - Т. 1. - С. 146-152.

4. Коритко 3. І. Вплив Омега-3 поліненасичених жирних кислот на функціонально-метаболічний гомеостаз та працездатність кваліфікованих бігунів / 3. І. Коритко, С. В. Онищук // Вісн. пробл. біології і медицини. - 2011. - Т. 3(89), вип. 3. - С. 150-156.

5. Корытко 3. И. Коррекция функционального состояния и работоспо-собности в условиях стресса с помощью полиненасыщенных жирных кислот «Омега-3» / 3. И. Корытко, С. В. Онищук // Немедикаментозная оптимизация состояния человека. - Тамбов: Изд. дом ТГУ им. Г. Р. Державина, 2010. - С. 67-71.

6. Монастирський В. А. Тромбін-плазмінова система - одна з основних регуляторних систем організму / В. А. Монастирський. - Л.: Ліга-Прес, 2007. - 228 с.

7. Мартынов А. И. Омега-3 полиненасыщенные жирные кислоты в кардиологической практике. Фармакологические эфрфекты и терапевтическое применение: метод. рекомендации / А. И. Мартынов, В. В. Чельцов. - М., 2007. - 22 с.

8. Морозова Н. А. Вивчення впливу препарату Теком на фрагоцитарну ланку імунітету у хворих на запальні захворювання бронхо-легеневої системи / Н. А. Морозова // Укр. пульмонол. журн. - 2000. - № 4. - С. 48-51.

9. Онищук С. В. Підвищення фрізичної працездатності бігунів на короткі дистанції у передзмагальному мезоциклі шляхом використання природних джерел Омега-3 / С. Онищук, 3. Коритко, В. Конестяпін [та ін.] // Молода спорт. наука України, 2011. - Т.1, вип.15. - С. 215-221.

10. Патент №53540 U Україна, МПК: А61К 35/00, А61 P 3/00. Спосіб підвищення функціональних можливостей, толерантності до навантаження та працездатності спортсменів / 3. І. Коритко; заявл. 12.04.2010; опубл. 11.10.2010, Бюл. № 19.
Висновки. Встановлено, що вплив тваринних і рослинних джерел поліненасичених жирних кислот Омега-3 на варіабельність серцевого ритму у спортсменів, в основному, мав схожий характер.

Результати досліджень дають підставу стверджувати, що для формування фрункціонального резерву спринтерам достатньо 300 мг ЕПК/ДГК чи 600 мг АЛК (як попередника ейкозаноїдів) Омега-3 на добу протягом місяця i, очевидно, повторення їх 3-4 рази в рік, оскільки, згідно з літературними даними, ефект від прийому курсу препаратів утримується 2-3 міс. [18].

Перспективи подальших розвідок. Детальніше вивчення впливу Омега-3 ПНЖК з метою розробки рекомендацій для застосування їх як одного з елементів стимуляції працездатності та відновлення спортсменів.

\section{References}

1. Aronov D. M. Cardiovascular system and Omega-3 polyunsaturated fatty acids / D. M. Aronov // Cardiology. - Access mode: http://www.rusmg.ru/php/contents. php?group $=144$

2. Gavrisiuk V. K. Usage of Omega-3 polyunsaturated fatty acids in medicine / V. K. Gavrisiuk // Ukr. pulmonolog. zhurn. - 2001. - N 3. - P. 5-10.

3. Korytko Z. Influence of plant adaptogenes on work capacity and indices of speed-strength preparation of track and field sprinters / Z. Korytko, S. Onyschuk, N. Semenova // Moloda sport. nauka Ukrainy. - 2010. - Vol. 1. P. $146-152$.

4. Korytko Z. I. Influence of Omega-3 polyunsaturated fatty acids on functional and metabolic homeostasis and work capacity of skilled runners / Z. I. Korytko, S. V. Onyschuk // Visn. probl. biolohii i medytsyny. - 2011. - Vol. 3(89), iss. 3. - P. 150-156.

5. Korytko Z. I. Correction of functional state and work capacity under stress conditions by means of Omega- 3 polyunsaturated fatty acids / Z. I. Korytko, S. V. Onischuk // Drug-free optimization of human state. - Tambov: Publishing House of TSU named after G. R. Derzhavin, 2010. P. 67-71.

6. Monastyrsky V. A. Thrombin-plasma system - one of the main regulatory systems of the body / V. A. Monastyrsky. L.: Liha-Pres, 2007. - 228 p.

7. Martynov $A$. I. Omega-3 polyunsaturated fatty acids in cardiology. Pharmacological effects and therapeutic application: methodical recommendations / A. I. Martynov, V. V. Cheltsov. Moscow, 2007. - 22 p.

8. Morozova N. A. Study of Tekom preparation impact on phagocytic link of immunity in patients with inflammatory diseases of bronchopulmonary system / N. A. Morozova // Ukr. pulmonol. zhurn. - 2000. - N 4. - P. 48-51.

9. Onyschuk S. V. Improvement of physical work capacity of short-distance runners at precompetitive mezocycle by using natural resources of Omega-3 / S. Onyschuk, Z. Korytko, V. Konestiapin [et al.] // Moloda sport. nauka Ukrainy, 2011. - Vol. 1, iss.15. - P. 215-221.

10. Patent N53540 U Ukraine, MPK: A61K 35/00, A61 $P 3 / 00$. Way of improving functional capacities, tolerance to loads and work capacity of athletes / Z. I. Korytko; appl. 12.04.2010; publ. 11.10.2010, Bul. N 19. 
11. Перепеч Н. Б. Применение Омега-3 полиненасыщенных жирных кислот - дополнительная возможность улучшения прогноза больных ишемической болезнью сердца / Н. Б. Перепеч / / Сердце. - 2007. - № 2. - С. 12-16.

12. Рекомендуемые уровни потребления пищевых и биологически активных веществ // Метод. рекомендации MP 2.3.1.1915-04 - 2004. - М.

13. Решетняк Т. М. Принципы лечения антифросфолипидного синдрома при системной красной волчанке / Т. М. Решетняк, 3. С. Алекберова, Е. Л. Насонов // Терапевт. арх., 1998. - № 70(5). - С. 83-87.

14. Сорока Н. Ф. Обоснование применения Эйконола при ревматических заболеваниях / Н. Ф. Сорока // Мед. новости, 1999. - № 4. - С. 47-50.

15. Barcelli U. O. Enhancing effect of dietary supplementation with Omega-3 fatty acid on plasma fibrinolysisin normal subject / U. O. Barcelli, V. E. Glass-Greenwalt // Pollak Thromb. Res. - 1985. - N 39. - P. 307-312.

16. Bittiner S. B. A double-blind, randomised, placebo-controlled trial of fish oil in psoriasis / S. B. Bittiner, W. F. Tucker, I. A. Cartwright / / Lancet. - 1988. - N 1. P. 378-380.

17. Brouwer I. A. Effect of fish oil on ventricular tachyarrhythmia and death in patients with implantable cardioverter defibrillators. The studyon Omega-3 fatty acid sand ventricular arrhythmia (SOFA) randomized trial / I. A. Brouwer // JAMA. - 2006. - Vol. 295. - P. 2613-2619.

18. Cardioprotective effect of Omega-3 polyunsaturated fatty acids / O. Moybenko, T. Kukoba, A. Shysh \& O. Kharchenko // J. Mol. Cell. Cardiol. - 2004. - Vol. 36, iss. 5. - P. 141.

19. Das U. N. Benefical effects of $\omega-3$ fatty acids in cardiovascular diseases: but, why and how? / U. N. Das // Prostaglandins, leucotrienes and Essential Fatty Acids. 2000. - Vol. 63, N 6. - P. 351-362.

20. Dempfle C. Sensitivity and specificity of a quantitative point of care D-dimer assay using heparinized whole blood, in patients with clinically suspected deep vein thrombosis / C. Dempfle, W. Korte, M. Schwab [et al.] // Thromb Haemost. - 2006. - Vol. 96. - P. 79-83.

21. Determination of the anaerobic threshold by a non invasive field test in runners / F. Conconi, M. Ferrari, P. G. Zig lio [et al.] // J. of Appl. Physiology. - 1982. - 52. - P. 869873.

22. Din J. N. Omega-3 fatty acids and cardiovascular disease - fish in gfor a natural treatment / J. N. Din / / BMJ. 2004. - N 328. - P. 30-35.

23. FDA announces qualified health claims for omega-3 fatty acids // Press release. - 2004. - September 8.

24. Kris-Etherton P. M. Fish consumption, fish oil, omega-3 fatty acid, and cardiovascular disease / P. M. KrisEtherton, W. S. Harris, L. J. Appel // Arterioscler. Thromb. Vasc. Biol. - 2003. - Vol. 23(2). - P. 20-30.

25. Leaf $A$. Clinical prevention of sudden cardiacdeathby $\omega-3$ polyunsaturated fatty acids and mechanism of prevention of arrhythmiasby $\omega-3$ fish oils. / A. Leaf // Circulation. 2003. - Vol. 107. - P. 2646-2652.

26. Mozaffarian D. Fish consumption and stroke risk in elderly individuals: the cardiovascular health study / D. Mozafferian // Arch. Intern. Med. - 2005. - Vol. 165(2). P. 200-206.

27. Rait M. Y. Fish oil supplementation and risk of ventricular tachycardia and ventricular fibrillation in patients with implant ablede fibrillators. A randomized controlled trial / M. Y. Rait // JAMA. - 2005. - Vol. 293.- P. 2884-2891.
11. Perepech N. B. USAGE OF Omega-3 polyunsaturated fatty acids - additional possibility to improve prognosis of patients with ischemic heart disease / N. B. Perepech // Serdtse. - 2007. - N 2. - P. 12-16.

12. Recommended levels of ingestion of nutrients and biologically active substances // Method. recommendations MR 2.3.1.1915-04 - 2004. - M.

13. Reshetniak T. M. Principles of treatment of antiphospholipid syndrome during systemic lupus erythematosus / T. M. Reshetniak, Z. S. Alekberova, Nasonov E. L. // Terapevt. arkhiv, 1998. - N 70(5). - P. 83-87.

14. Soroka N. F. Substantiation of Eikonol usage during rheumatic diseases / N. F. Soroka // Med. novosti, 1999. N 4. - P. 47-50.

15. Barcelli U. O. Enhancing effect of dietary supplementation with Omega-3 fatty acid on plasma fibrinolysisin normal subject / U. O. Barcelli, V. E. Glass-Greenwalt // Pollak Thromb. Res. - 1985. - N 39. - P. 307-312.

16. Bittiner S. B. A double-blind, randomised, placebo-controlled trial of fish oil in psoriasis / S. B. Bittiner, W. F. Tucker, I. A. Cartwright // Lancet. - 1988. - N 1. P. 378-380.

17. Brouwer I. A. Effect of fish oil on ventricular tachyarrhythmia and death in patients with implantable cardioverter defibrillators. The studyon Omega-3 fatty acid sand ventricular arrhythmia (SOFA) randomized trial / I. A. Brouwer // JAMA. - 2006. - Vol. 295. - P. 2613-2619.

18. Cardioprotective effect of Omega-3 polyunsaturated fatty acids / O. Moybenko, T. Kukoba, A. Shysh \& O. Kharchenko // J. Mol. Cell. Cardiol. - 2004. - Vol. 36, iss. 5. - P. 141.

19. Das U. N. Benefical effects of $\omega-3$ fatty acids in cardiovascular diseases: but, why and how? / U. N. Das // Prostaglandins, leucotrienes and Essential Fatty Acids. 2000. - Vol. 63, N 6. - P. 351-362.

20. Dempfle C. Sensitivity and specificity of a quantitative point of care D-dimer assay using heparinized whole blood, in patients with clinically suspected deep vein thrombosis / C. Dempfle, W. Korte, M. Schwab [et al.] // Thromb Haemost. - 2006. - Vol. 96. - P. 79-83.

21. Determination of the anaerobic threshold by a non invasive field test in runners / F. Conconi, M. Ferrari, P. G. Ziglio [et al.] // J. of Appl. Physiology. - 1982. - 52. - P. 869873.

22. Din J. N. Omega-3 fatty acids and cardiovascular disease - fish in gfor a natural treatment / J. N. Din / / BMJ. 2004. - N 328. - P. 30-35.

23. FDA announces qualified health claims for omega-3 fatty acids // Press release. - 2004. - September 8.

24. Kris-Etherton P. M. Fish consumption, fish oil, omega-3 fatty acid, and cardiovascular disease / P. M. KrisEtherton, W. S. Harris, L. J. Appel // Arterioscler. Thromb. Vasc. Biol. - 2003. - Vol. 23(2). - P. 20-30.

25. Leaf $A$. Clinical prevention of sudden cardiacdeathby $\omega-3$ polyunsaturated fatty acids and mechanism of prevention of arrhythmiasby $\omega-3$ fish oils. / A. Leaf // Circulation. 2003. - Vol. 107. - P. 2646-2652.

26. Mozaffarian D. Fish consumption and stroke risk in elderly individuals: the cardiovascular health study / D. Mozafferian // Arch. Intern. Med. - 2005. - Vol. 165(2). P. 200-206.

27. Rait M. Y. Fish oil supplementation and risk of ventricular tachycardia and ventricular fibrillation in patients with implant ablede fibrillators. A randomized controlled trial / M. Y. Rait // JAMA. - 2005. - Vol. 293.- P. 2884-2891. 